УДК 638.8:633.11:631.445.4 (292.485)

(C) 2012

Глущенко Л. Д., кандидат сільськогосподарських наук,

Калініченко С. М., Дорощенко Ю. І., Білан В. М., Запорожець Л. М., співробітники

Полтавський інститут АПВ ім. М. І. Вавилова

Біланович О. Л., співробітник

Полтавський центр «Облдержродючість»

\title{
ЕКОНОМІЧНА ТА ЕНЕРГЕТИЧНА ЕФЕКТИВНІСТЬ ЗАСТОСУВАННЯ РІЗНИХ СИСТЕМ УДОБРЕННЯ ПІД ПШЕНИЦЮ ОЗИМУ НА ЧОРНОЗЕМІ ТИПОВОМУ
}

\section{Рецензент - кандидат сільськогосподарських наук А. В. Сидоренко}

\begin{abstract}
Застосування добрив є одним із найважливіших напрямів підвищення продуктивності сільськогосподарських культур та покращання родючості трунту. Зі збільшенням доз мінеральних добрив зростала собівартість 1 и зерна пшениці озимої та зменшувався умовно-чистий прибуток $і$ коефiцієнт енертетичної ефективності. Експлуатація трунту без застосування сучасних технологій вирошування сільськогосподарських культур і зокрема без внесення добрив (як одного із заходів відтворення його родючості) призведе до катастрофічного зниження родючості грунту.
\end{abstract}

Ключові слова: дози мінеральних добрив, родючість трунту, коефіцієнт енертетичноі ефективності.

Постановка проблеми. Початок третього тисячоліття ознаменувався підвищенням інтересу до продовольчої та енергетичної безпеки в світі. Вона може розглядатися як один із найважливіших аспектів формування високого рівня якості життя країни, поскільки саме споживання продуктів харчування $є$ базовою 3-поміж людських потреб $[1,6]$. Основними індикаторами, що характеризують стан продовольчої безпеки України, є добова енергетична цінність споживання забезпечення раціону людини основними видами продуктів і достатність запасів зернових продовольчих ресурсів $[7,8]$.

В останні роки як у світовій практиці, так і в Україні простежується тенденція до зниження витрат на вирощування сільськогосподарських культур, зокрема пшениці озимої.

Аналіз основних досліджень і публікацій, у яких започатковано розв'язання проблеми. Добрива - потужний фактор підвищення врожайності культур і продуктивності сільського господарства в цілому. За даними Комісії з харчування $\mathrm{OOH} \mathrm{(ФАО),} \mathrm{частка} \mathrm{добрив} \mathrm{у} \mathrm{форму-}$ ванні врожаю становить 30-50\%, а в прирості врожаю - 50-70 \%. В Україні цей показник ко- ливається в межах від 30 до $40 \%$, який, у свою чергу, залежить від клімату, родючості грунту, рівня агротехніки, норм і якості добрив та інших факторів [3]. Затрати на застосування добрив знаходяться в межах 10-25 \% від загальних затрат. Для вибору та впровадження у виробництво найефективніших норм, форм, способів i строків внесення добрив необхідна їх економічна оцінка [5].

I3 кожним роком підвищуються вимоги до поліпшення використання добрив i збільшення економічної ефективності їх застосування. Кожна тонна, кожен центнер добрив має сприяти отриманню більшої кількості продукції рослинництва високої якості. Такі вимоги набувають особливої актуальності в умовах ринкових відносин, відповідних форм оплати праці й економічних взаємовідносин, а також у зв'язку з підвищенням цін на добрива, технічні засоби та їх амортизацію й оплату менеджменту $[4,10]$.

Обгрунтовуючи використання добрив, критерієм їх економічної ефективності є обсяг виробництва продукції та ресурсоємність ії одиниці. В даному випадку показниками оцінки є врожайність, затрати живої праці на одиницю продукції, окупність урожаєм виробничих ресурсів; сумарні експлуатаційні витрати на одиницю продукції; чистий прибуток із гектара. Для економічної оцінки необхідно визначити витрати на використання добрив у повному обсязі $[2,8]$.

Мета досліджень та методика їх проведення. Висока вартість ресурсів усе більше зумовлює спрощення методів роботи й економії затрат. Наразі назріла гостра потреба у вивченні оптимальних систем удобрення з різними співвідношеннями та видами органічних і мінеральних добрив.

У зв'язку 3 цим метою наших досліджень $\epsilon$ визначення економічно вигідного варіанту, за якого будуть використані менш затратні енергії 
на виробництво одиниці врожаю, тобто, на перше місце вийдуть не економічні, а енергетичні критерії застосування добрив.

Об'єктами досліджень були польові та лабораторні дослідження, що проводилися в стаціонарному досліді Полтавського інституту АПВ ім. М. І. Вавилова в селищі Степне Полтавського району на чорноземі типовому середньогумусному важкосуглинковому. В (0-20 см) шарі грунту гумусу 4,9\%, азоту (за методом Корнфілда) - 15,1 мг; рухомих форм (за методом Чирикова) $\mathrm{P}_{2} \mathrm{O}_{5}-6,9$ мг i $\mathrm{K}_{2} \mathrm{O}-14,9$ мг / 100 г грунту.

Дослід проводиться в семипільній сівозміні: 1 - кукурудза на силос; 2 - пшениця озима; 3 - соя; 4 - ячмінь; 5 - горох; 6 - пшениця озима; 7 - кукурудза на зерно. Всі культури вирощуються за інтенсивними технологіями .

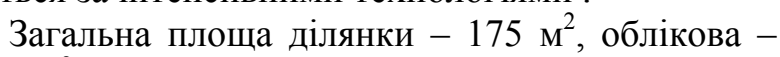
$100 \mathrm{~m}^{2}(25 \times 4)$. Повторність - триразова.

Схема досліду:

Без добрив (контроль)

Післядія гною

Післядія гною $+\mathrm{N}_{45} \mathrm{P}_{45} \mathrm{~K}_{45}$

Післядія соломи пшениці озимої

Післядія соломи пшениці озимої $+\mathrm{N}_{45} \mathrm{P}_{45} \mathrm{~K}_{45}$

Солома гороху 4 т/га $+\mathrm{N}_{40}$

Солома гороху 4 т/га $+\mathrm{N}_{85} \mathrm{P}_{45} \mathrm{~K}_{45}$.

Результати досліджень. При обгрунтуванні й використанні тієї або іншої системи удобрення критерієм економічної ефективності є обсяг ви- робництва продукції, ресурсоємність іiі одиниці та вплив на зміну природної родючості грунту.

Аналіз урожайних даних свідчить про позитивний вплив добрив на продуктивність пшениці озимої (табл. 1).

Відносний приріст урожаю зерна від застосування добрив до абсолютного контролю знаходилась у межах від 3,6 ц/га до 9,6 ц/га, або в процентах - від 11,1\% (післядія гною) до 29,5\% (післядія соломи пшениці озимої $+\mathrm{N}_{45} \mathrm{P}_{45} \mathrm{~K}_{45}$ ).

Застосування мінеральних добрив на тлі органічних або їх післядія, при невисокому рівні врожайності пшениці озимої, дещо зменшило умовно-чистий дохід і підвищило собівартість 1 ц зерна, відносно органічної системи удобрення.

3 іншого боку, за інтенсивних систем удобрення рівень врожайності зерна пшениці озимої, нижче якого виробництво культури збиткове, є вищим.

Витрати енергіï на 1 ц врожаю і коефіцієнт енергетичної ефективності значною мірою залежить від системи удобрення.

Застосування під пшеницю озиму мінеральних добрив на тлі дії соломи горохової та післядії соломи пшениці озимої дещо погіршило економічні показники, однак водночас без внесення мінеральних і органічних добрив родючість грунту погіршується (табл. 2).

\section{1. Економічні показники у процесі вирощування пшениці озимої після гороху}

\begin{tabular}{|c|c|c|c|c|c|c|c|}
\hline \multirow{2}{*}{ Показники } & \multicolumn{7}{|c|}{ Варіанти удобрень } \\
\cline { 2 - 8 } & $\begin{array}{c}\text { добрив } \\
\text { конт- } \\
\text { роль) }\end{array}$ & $\begin{array}{c}\text { післядія } \\
\text { гною }\end{array}$ & $\begin{array}{c}\text { післядія } \\
\text { гною } \\
\mathrm{N}_{45} \mathrm{P}_{45} \mathrm{~K}_{45}\end{array}$ & $\begin{array}{c}\text { післядія } \\
\text { соломи } \\
\text { пшениці } \\
\text { озимої }\end{array}$ & $\begin{array}{c}\text { післядія } \\
\text { соломи } \\
\text { пшениці } \\
\text { озимої+ } \\
\mathrm{N}_{45} \mathrm{P}_{45} \mathrm{~K}_{45}\end{array}$ & $\begin{array}{c}\text { солома } \\
\text { гороху } \\
4 \text { т/га }+ \\
\mathrm{N}_{40}\end{array}$ & $\begin{array}{c}\text { солома } \\
\text { гороху } \\
4 \text { т/га }+ \\
\mathrm{N}_{85} \mathrm{P}_{45} \mathrm{~K}_{45}\end{array}$ \\
\hline $\begin{array}{c}\text { Урожайність, } \\
\text { ц/га }\end{array}$ & 32,5 & 36,1 & 41,0 & 6,8 & 42,1 & 40,6 & 40,5 \\
\hline $\begin{array}{c}\text { Приріст зерна } \\
\text { від добрив, ц/га }\end{array}$ & - & 3,6 & 8,5 & 4,3 & 9,6 & 8,1 & 8,0 \\
\hline $\begin{array}{c}\text { Вартість врожаю, } \\
\text { грн }\end{array}$ & 3900 & 4332 & 4920 & 4416 & 5052 & 4872 & 4860 \\
\hline Витрати, грн/га & 1174 & 1272 & 3528 & 272 & 358 & 3681 & 3222 \\
\hline $\begin{array}{c}\text { Умовно-чистий } \\
\text { прибуток, грн }\end{array}$ & 2726 & 3060 & 1392 & 3144 & 1534 & 1191 & 1638 \\
\hline $\begin{array}{c}\text { Собівартість 1 ц зерна, } \\
\text { грн }\end{array}$ & 36 & 35 & 86 & 35 & 84 & 41 & 80 \\
\hline $\begin{array}{c}\text { Рівень врожайності, } \\
\text { нижче якого }\end{array}$ & 10 & 11 & 29 & 11 & 29 & 14 & 27 \\
\hline $\begin{array}{c}\text { виробництво культури } \\
\text { збиткове, ц }\end{array}$ & 10 & & & & & \\
\hline
\end{tabular}




\section{2. Енергетична ефективність різних систем удобрення у процесі вирощування пиениці} озимої

\begin{tabular}{|c|c|c|c|}
\hline \multirow{2}{*}{ Системи удобрення } & \multicolumn{2}{|c|}{ Енергія, МДж/га } & \multirow{2}{*}{$\begin{array}{l}\text { Коефіцієнт енергетич- } \\
\text { ної ефективності }\end{array}$} \\
\hline & затраченої & відтвореної & \\
\hline Без добрив (контроль) & - & - & - \\
\hline Післядія гною & 414 & 9101 & 22,0 \\
\hline Післядія гною $+\mathrm{N}_{45} \mathrm{P}_{45} \mathrm{~K}_{45}$ & 6260 & 40502 & 6,5 \\
\hline Післядія соломи пшениці озимої & 520 & 11126 & 21,3 \\
\hline $\begin{array}{c}\text { Післядія соломи пшениці озимої + } \\
\mathrm{N}_{45} \mathrm{P}_{45} \mathrm{~K}_{45}\end{array}$ & 4975 & 40061 & 8,1 \\
\hline Солома гороху 4 т/га $+\mathrm{N}_{40}$ & 620 & 12768 & 20,6 \\
\hline Солома гороху 4 т/га $+\mathrm{N}_{85} \mathrm{P}_{45} \mathrm{~K}_{45}$ & 5263 & 39291 & 20,6 \\
\hline
\end{tabular}

Найвищими коефіцієнтами енергетичної ефективності (КЕЕ) характеризувалися посіви з органічною системою удобрення, або їх післядія (гній, побічна продукція) і знаходилися в межах 20,6-22,0 одиниць. Меншими ці показники були там, де застосовували мінеральні добрива на тлі органічних.

\section{БІБЛІОГРАФІЯ}

1. Голубев А. В. Эколого-экономическая оценка применения удобрений / А. В. Голубев // Земледелие. - 1991. - № 3. - С. 63-65.

2. Глобалізація і безпека розвитку (текст) монографія / М. О. Гончаренко, В. А. Зленко, А. В. Зернацька [та ін.]. Під заг. ред. О. Г. Білоpyc. - К.: КНЕУ. - 2001. - 733 c.

3. Городній M. М. Агрохімія. Підручник // М. М. Городній. - 4-те вид., перероб. і допов. К.: Арістей, 2008. - 936 с.

4. Зінченко О. І. Рослинництво. / За ред. О. І. Зінченка / О. І. Зінченко, В. Н. Салатенко, М. А. Білоножко. - К.: Аграрна освіта, 2001. - 591 с.

5. Наукове забезпечення сталого розвитку сільського господарства в Лісостепу України. - К.: Алефа, 2003. - $886 \mathrm{c}$.

6. Наукові основи ведення зернового господарства / Сайко В. Ф., Лобас М. Г., Яновський І. В. [та ін.] / За заг. ред. В. Ф. Сайка. - К.: Урожай,
Висновки. Найнижчою собівартість 1 ц зерна пшениці озимої була на ділянках із післядією гною і соломи (35 грн/ц), а умовно-чистий прибуток склав, відповідно, 3060 і 3144 гривень.

За цих систем удобрення був і максимальний коефіцієнт енергетичної ефективності - 22,0 і 21,3 одиниці.

1994. $-336 \mathrm{c}$.

7. Постанова Кабінету Міністрів України від 05.12.2007 № 1379 «Деякі питання продовольчої безпеки» (Електронний ресурс).

8. Ульянченко О.В. Залежність продовольчої безпеки країни від забезпеченості аграрної сфери ресурсами (Текст) / О.В. Ульянченко // Агросвіт. - 2007. - № 9. - С. 4-8.

9. Хомчак О. М., Хомчак М. Ю., Полтореиъкий С. П. Енергетична ефективність різних норм мінеральних добрив при вирощуванні овочевого гороху на різних грунтах // Вісник Полтавської державної аграрної академії, 2006. - № 2. - С. 78-80.

10. Щиткин B. В. Значение удобрений в интенсивных технологиях / В. В. Щеткин // Рынок минеральных удобрений и агрохимии, 2004, (конф.), 19-20 февраля. - Алушта, 2004. C. 83-90. 